\title{
Prioritizing Commodities in Southeast Sulawesi Province of Indonesia Using AHP Based Borda Count Method
}

\author{
Haji Saediman $^{1}$ \\ ${ }^{1}$ Dept of Agribusiness, Faculty of Agriculture, Halu Oleo University, Kendari, Indonesia \\ Correspondence: Haji Saediman, Dept of Agribusiness, Faculty of Agriculture, Halu Oleo University, Kampus \\ Bumi Tridarma Anduonohu, Kendari 93232 Sulawesi Tenggara, Indonesia. Tel: 62-813-5632-0088. E-mail: \\ saediman@yahoo.com
}

Received: January 12, 2015 Accepted: March 9, 2015 Online Published: May 15, 2015

doi:10.5539/ass.v11n15p171 URL: http://dx.doi.org/10.5539/ass.v11n15p171

\begin{abstract}
This study aimed to determine the priority of agricultural commodities in the province of Southeast Sulawesi, Indonesia using combination of AHP (Analytical Hierarchy Process) and Borda Count (BC). In this way, pairwise comparison among alternative commodities was done using AHP, and the AHP ranking was then analyzed with BC. Six districts out of 12 districts in the province were selected as study location. Data and information were obtained through questionnaire survey and interviews with 30 decision makers (DMs) from district-level government institutions. Selected DMs came from (i) food crops division, (ii) estate crops division, (iii) livestock division, (iv) fisheries division, and (v) development planning agency. Study results show that districts have different priority commodities depending on their agroecological characteristics and socio-economic conditions. At the province level, the first priority commodity is sea weed, and the other top nine priority commodities in order of ranking are rice, cocoa, beef cattle, maize, cashew nut, skipjack tuna, coconut, cassava, and citrus. The method has been proven robust, simple, flexible, and adequate to achieve the study objectives. This information about priority commodities can be used by the provincial government to renew its focus on developing agriculture sector.
\end{abstract}

Keywords: agriculture, AHP, Borda Count, commodity, Indonesia, priority commodities

\section{Introduction}

Agricultural sector in broad term covering food crops, estate crops, livestock, fisheries, and forestry has contributed significantly to the overall economic and social development in Indonesia through its large share to GDP, generation of employment, source of foreign exchange, supply of basic foods, and source of income for the majority of people living in rural areas (FAO, 2001). However, in Southeast Sulawesi province, in the last seven years there has been declining trend in such roles. As Table 1 shows, the proportion of labor force working in agriculture decreased from $60 \%$ in 2006 to $45.3 \%$ in 2011 . The share of agricultural sector to Gross Regional Domestic Product (GRDP) decreases from 40.7\% in 2006 to 31.7\% in 2011, with its growth rate declining from $4.57 \%$ in 2006 to $2.56 \%$ in 2011 . On the other hand, there has been increased share of other sectors, especially mining, which is booming after local governments sought to exploit resource endowments to drive development. The growth of mining sector increases from $6.0 \%$ in 2009 to $35.1 \%$ in 2011. Such phenomenon reflects a changing priority of the local government on policy and investment in agriculture. At the same time, the poor performance of agriculture confirms the issues the province has faced as it seeks to develop the agricultural sector, such as low productivity, rigid production and trade structure, a limited skills base, poor infrastructure, lack of access to capital, and inadequate institutional and policy framework (FAO, 2001).

Table 1. Growth of agriculture and its share in employment and GRDP in Southeast Sulawesi Province, 2006-11

\begin{tabular}{lcccccc}
\hline \multicolumn{1}{c}{ Indicator } & 2006 & 2007 & 2008 & 2009 & 2010 & 2011 \\
\hline GRDP Growth & $7.68 \%$ & $7.96 \%$ & $7.27 \%$ & $7.57 \%$ & $8.22 \%$ & $8.96 \%$ \\
Agriculture growth & $4.57 \%$ & $5.60 \%$ & $5.04 \%$ & $2.73 \%$ & $1.28 \%$ & $2.56 \%$ \\
Share of agriculture in GDRP & $40.73 \%$ & $38.12 \%$ & $36.53 \%$ & $35.02 \%$ & $33.34 \%$ & $31.67 \%$ \\
Share in Employment & $60.0 \%$ & $57.0 \%$ & $58.0 \%$ & $53.0 \%$ & $49.7 \%$ & $45.3 \%$ \\
\hline
\end{tabular}

Source: BPS Sulawesi Tenggara, 2013 
The changing structure of economy of the province requires attention in the context of overall economic and social development. If not done in sustainable ways, the expansion of mining could result in deterioration of environmental and natural resources which in longer term would cause negative consequences to the economic growth and development itself. As economy develops, the comparative advantage of a region's economy would shift to non-farm sectors (Otsuka, 2012), but such relative decline of agriculture should not be used as a signal to ignore the sector (Timmer, 2012). At the same time, without developing more fully the potential human and productive capacity of the agricultural sector and enhancing its contribution to overall economic and social development, efforts of promoting economic growth, reducing poverty, and enhancing food security cannot be fully achieved (FAO, 2001). Therefore, there should be a renewed focus on agricultural development. The provincial government needs to revisit its agricultural and rural development strategies in order to raise and sustain productivity and competitiveness, diversify production and trade, and increase income of farmers (OECD, 2012). Such strategies need to be based on agribusiness approach, which develops particular commodities integratedly covering upstream, on-farm, and downstream subsystems, including supporting subsystem. To be effective, however, the government may need to focus more on several priority commodities selected from a pool of agricultural commodities in all districts.

Priority commodities are commodities that have comparative advantages and potential competitive advantages. Widayanto (2000) and Nainggolan (2011) provided several criteria for the priority commodities, such as (a) suitable with agroecological condition of the area, (b) has high market demand or potential, (c) providing significant income to the people, (d) cultivated or developed by a large proportion of population, and (e) availability of supporting factors such as institutions, technology, capital, input and infrastructure, and labor force. To guide the decision making process of selecting priority commodities using these criteria, a simple, systematic, and logical method is needed. According to Rao (2013), the objective of a selection procedure is to identify appropriate selection criteria, and to obtain the most appropriate combination of criteria in conjunction with the real requirements. Thus, attributes that influence an alternative selection for a particular issue should be identified using simple and logical methods to find out suitable list of alternatives and to select the most appropriate alternatives to strengthen the existing selection procedures.

Analytical Hierarchy Process (AHP) is one of the well-known and widely used multicriteria decision making methods relying on the comparative evaluation of criteria/alternatives (Saaty, 1980). AHP method helps in structuring the hierarchy of attributes and alternatives for evaluation and provides assessment of decision makers' evaluation by pair-wise comparisons (Darji \& Rao, 2013). It is widely applied for its simplicity and because it allows relationships between factors (criteria and alternatives) to be established according to the judgment of decision makers expressed as ordinal language and then converted into cardinal numbers (Vizzari \& Modica, 2013).

This study aimed to determine the priority of agricultural commodities in the province of Southeast Sulawesi. The proposed method in this paper is the combination of AHP and Borda Count (BC) method. A Borda Count is a technique that allows a decision maker to rank available alternatives by providing different preferences to each alternative. Analytical framework and procedures used in this study was adapted from Claudio, Chen, and Okudan (2008), in which the pairwise comparisons are done using AHP, followed by the application of BC to give points or scores to each alternative, which will then be summed up to obtain the final rankings of commodities.

\section{Method}

\subsection{Study Location}

The study was conducted in the province of Southeast Sulawesi. The province is located between the coordinates $2^{\circ} 45^{\prime}-6^{\circ} 15^{\prime}$ of south latitudes and longitudes $122^{\circ} 45^{\prime}-124^{\circ} 45^{\prime}$ east. It has a land size of $38,140 \mathrm{~km}^{2}$ and sea water area of $110,000 \mathrm{~km}^{2}$. The province has several main islands, such as Buton, Muna, Wawonii, Wakatobi, and Kabaena, but the larger part of its land lies on the southeast peninsula of Sulawesi Island. The average maximum temperature varies between $29^{\circ} \mathrm{C}$ and $32^{\circ} \mathrm{C}$ and minimum temperature between $22^{\circ} \mathrm{C}$ and $24^{\circ} \mathrm{C}$. With respect to rainfall, the province can be divided into areas with mean annual rainfall more than $2000 \mathrm{~mm}$, and areas with mean annual rainfall less than $2000 \mathrm{~mm}$. The major economic activity of the inhabitants is agriculture. Like any other areas in Indonesia, the province has a tropical climate marked by dry season usually from June to September and rainy reason from December to March. The climatic condition, soil type, topography, vegetation cover, and marine water support the production of several commodities such rice, cassava, cashew nut, cocoa, sea weed, skipjack tuna, corn and beef cattle. In 2012, the province has a population of 2.4 million people, with a population density of 63 people per sq. $\mathrm{km}$. 
Selection of study district was based on the criteria of (i) geographical location, (ii) similarities in agro-ecological conditions, and (iii) ethnic representation. Using these criteria, of the total 12 districts in the province, six districts were selected as the study locations, namely Kolaka, Konawe, South Konawe, Buton, Muna, and Wakatobi. The first three districts are situated in the mainland while the other three are in the islands in the province.

\subsection{Selection of Decision Makers}

In administering a survey which is based on judgment of experts, selection of experts with suitable experience and knowledge is essential. This is because of difficulty to achieve a consensus among experts from various disciplines (Shapira, Shoshany, \& Nir-Goldenberg, 2013). In this study, respondents were Decision Makers (DMs) at district level government institutions. They were heads of divisions who usually have technical knowledge and skills and, at the same time, a significant role in the decision making process in his or her office. In addition, as priority commodities in a district may represent or come from different subsectors (food crops, estate crops, livestock, and fisheries), different subsectors may present different views with respect to the criteria's weight distribution. In order to balance these likely different views, DMs were selected not only from agriculture related offices, but also from District Development Planning Agency. Thus, in each district, selected DMs came from (i) food crops division, (ii) estate crops division, (iii) livestock division, (iv) fisheries division, and (v) development planning agency. Five DMs were selected from each district, so the total number of DMs was 30. However, for AHP questionnaires, one response from Kolaka District and one from Konawe District were excluded because their Consistency Ratio (CR) was higher than 0.1. As Saaty (1980) has pointed out, CR more than 0.1 indicates unacceptable inconsistency in the subjective judgements of DMs. Therefore, the total questionnaire responses further analyzed were only 28.

\subsection{Data Collection}

Data and information were collected through desk review, questionnaires, and in-depth interviews. Desk review was used to collect information about the priority commodities in each district. Sources of information included provincial and district government strategic plans, and related regulation, policies, and programs. An AHP questionnaire survey of selected DMs was conducted based on the method of pairwise comparison (Ichihara \& Uchida, 2014). For this purpose, the questionnaire was provided in person to every DM, during which the researcher explained the objectives of the study, the criteria used to evaluate commodities, the hierarchy of the decision problem, and the procedure for completing the questionnaire. All DMs acknowledged that it was the first time they encountered and filled AHP questionnaire. The completed questionnaire was collected from each DM 2-3 days later. During this time the researcher interviewed him or her regarding priority commodities in the district and related policies and programs to promote them in order to complement the quantitative results of AHP.

\subsection{Data Analysis}

\subsubsection{Combining AHP and BC}

AHP is one of the most popular and powerful techniques for decision making in use today (Claudio et al., 2008), and has been applied widely in various categories such as selection, evaluation, benefit-cost analysis, allocation, planning and development, priority and ranking, decision making, forecasting, medicine and related fields (Vaidya \& Kumar, 2006). AHP's main uniqueness is its inherent capability of weighting a great number of different factors, which can be qualitative or quantitative, to support decision making, thereby producing a formal and quantitative basis for the solution (Saaty, 1980).

In addition, instead of just saying which alternative is preferred, AHP also gives a magnitude of how much one alternative is preferred over another. It uses a standard scale of numbers from 1 meaning no preference up to 9 , meaning that one alternative is extremely preferred over another. The judgments are used in deriving ratio scale priorities for the decision criteria and alternatives (Dyer \& Forman, 1992).

With AHP based evaluation, each expert ranks all alternatives in the order of preference from the first choice to the last choice. So the next task is to aggregate the individual decisions of each expert and create a so-called group decision. There are different ways to accomplish this, such as voting, finding the compromise, building the consensus, the arithmetic or geometric aggregation of priorities or judgments, etc. (Srdjevic, Lakicevic, \& Srdjevic, 2013). In this study, the proposed approach is to use Borda count method (Claudio et al., 2008). BC is based on rank numbers of alternatives in the experts' preference rankings. Each rank is assigned a number and the difference between two consecutive rank numbers is 1 (Nurmi, 2004). In this regard, each commodity is given a point corresponding to the position in which it is ranked by the participant. The number of points given 
to commodities for each ranking is determined by the number of commodities being evaluated. If there are $n$ commodities, then a commodity will receive $n$ points for a first preference, $n-1$ points for a second preference, n-2 for the third, and so on, with a commodity receiving 1 point for being ranked last. Once all preferences have been counted the commodity with the most points is the winner, and their points will reflect their rank in the district. At the provincial level, commodities from all districts were compiled and the count method was again used to determine the final rank of the commodities. The total point for each commodity determined its rank in the province.

\subsubsection{Procedures of AHP and BC Methods}

In order to attain the objective of the study, AHP and BC methods were applied with the procedures as follows:

1) Identification of goal, criteria, and alternatives

The goal in this study is to find out and rank the priority agricultural commodities in the province. This will be done first by identifying priority commodities in each district. The criteria for determining priority commodities in the district included (i) provision of employment or the number of households relying their earnings on that commodity, (ii) market potential, (iii) production inputs and infrastructure, (iv) technology, (v) contribution of the commodity to the district economy, and (vi) policy support. Based on these criteria, after referring to statistics of agriculture and various planning documents and consulting to staff at Development Planning Agency at each district and in the province, the researcher predetermined 6-8 priority commodities in each district (Table 2). The number of pre-determined priority commodities in each district was not the same reflecting the differences in the policies and in the agroecological conditions and potentials in each district.

Table 2. Alternative commodities in each district that would be ranked using AHP and Borda Count

\begin{tabular}{lll}
\hline No & District & Priority commodities \\
\hline 1 & Kolaka & Rice, beef cattle, cocoa, clove, skipjack tuna, and sea weed \\
2 & Konawe & Rice, maize, cocoa, pepper, coconut, beef cattle, sea weed, and skipjack tuna \\
3 & Konawe Selatan & Rice, soybean, cocoa, citrus, beef cattle, sea weed, milkfish, and nile tilapia \\
4 & Buton & Maize, rice, cashew nut, coconut, citrus, sea weed, and skipjack tuna \\
5 & Muna & Rice, maize, cassava, beef cattle, cocoa, cashew nut, sea weed, and shrimp \\
6 & Wakatobi & Sea weed, skipjack tuna, grouper, Indian scad, coconut, cassava and goat \\
\hline
\end{tabular}

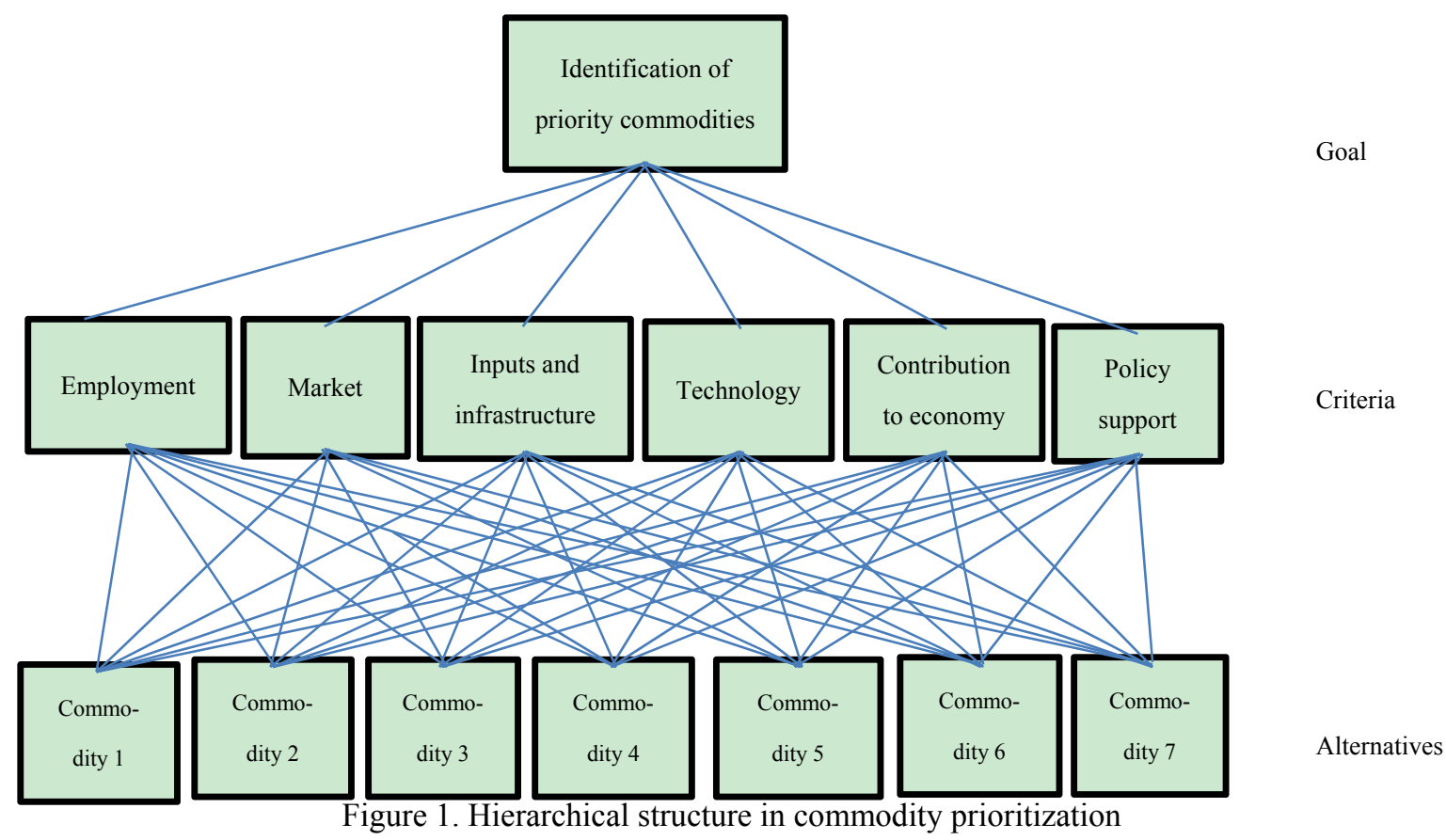

2) The decision model is developed in hierarchical form (Figure 1) in which the goal is positioned at the top with criteria at lower level and the alternatives at the bottom of the model (Motik, Šegotić, \& Jazbec, 2010; Junior, Perez, \& Boratto, 2010) 
3) At each hierarchy structural level, all possible pairs of the elements of that level are evaluated through pairwise comparisons. The decision-maker's preferences are expressed by verbally described intensities and the corresponding numerical values on the 1-3-5-7-9 scale (Saaty, 1980). On the basis of pairwise comparisons, relative significance (weights) of elements of the hierarchy structure are calculated, which are eventually synthesized into an overall alternatives priority list.

4) On the basis of AHP weights which have been obtained, BC is used to rank the alternatives. The alternative with the highest weight will get (n) points, while the lowest weight will get 1 point, where $n$ is the number of alternatives.

5) An AHP based BC chart is made. The table contains the values for the AHP weights multiplied by the BC values for each DM. The score for each alternative is summed and the highest total score means the best alternative in the district (Claudio et al., 2008).

6) At the province level, priority commodities from districts were given points based on their ranks. The points for each commodity were summed up and the total points obtained would determined its final rank.

\section{Results and Discussion}

\subsection{Ranking Commodities at the District Level}

\subsubsection{Kolaka District}

Based on six criteria provided, commodities have different weights in accordance with the results of questionnaires from respondents. Table 3 shows ranking of priority commodities in Kolaka District. Three DMs put cocoa in the first priority, and another DM put sea weed in the first priority. With the weight of 0.342 , cocoa was the first priority commodity. Based on the total points and weight obtained, the second priority commodity was clove, followed by rice, sea weed, skipjack tuna, and beef cattle.

Table 3. AHP based Borda results for ranking of commodities in Kolaka District

\begin{tabular}{|c|c|c|c|c|c|c|c|}
\hline \multirow{2}{*}{ Alternatives } & \multicolumn{4}{|c|}{ Score (AHP*BC) } & \multirow{2}{*}{ Total score } & \multirow{2}{*}{ Weight } & \multirow{2}{*}{ Ranking } \\
\hline & DM 1 & DM 2 & DM 3 & DM 4 & & & \\
\hline Cocoa & 1.638 & 1.800 & 0.318 & 2.136 & 5.892 & 0.342 & 1 \\
\hline Clove & 0.186 & 1.260 & 0.692 & 1.295 & 3.433 & 0.200 & 2 \\
\hline Rice & 1.110 & 0.342 & 0.489 & 0.880 & 2.821 & 0.164 & 3 \\
\hline Beef cattle & 0.688 & 0.101 & 0.040 & 0.222 & 1.051 & 0.061 & 6 \\
\hline Sea weed & 0.459 & 0.204 & 1.560 & 0.130 & 2.353 & 0.137 & 4 \\
\hline Skipjack tuna & 0.087 & 0.520 & 1.025 & 0.026 & 1.658 & 0.096 & 5 \\
\hline Influence Index & 4.168 & 4.227 & 4.124 & 4.689 & & & \\
\hline
\end{tabular}

\subsubsection{Konawe District}

Among eight priority commodities identified in Konawe district, rice was chosen as the first option by three DMs, and cocoa was selected as the first choice by one DM. As shown in Table 4, rice obtained the highest total score and weight, implying it to be the first priority commodity in the district. The second priority commodity was cocoa, and the subsequent priority commodities - in order of ranking - were sea weed, skipjack tuna, maize, pepper, beef cattle, and coconut.

Table 4. AHP based Borda results for ranking of commodities in Konawe District

\begin{tabular}{|c|c|c|c|c|c|c|c|}
\hline \multirow{2}{*}{ Alternatives } & \multicolumn{4}{|c|}{ Score (AHP*BC) } & \multirow{2}{*}{ Total score } & \multirow{2}{*}{ Weight } & \multirow{2}{*}{ Ranking } \\
\hline & DM 1 & DM 2 & DM 3 & DM 4 & & & \\
\hline Rice & 1.722 & 2.792 & 2.648 & 2.392 & 9.554 & 0.392 & 1 \\
\hline Maize & 0.308 & 0.816 & 0.228 & 0.3 & 1.652 & 0.068 & 5 \\
\hline Cocoa & 2.072 & 1.211 & 0.755 & 1.897 & 5.935 & 0.243 & 2 \\
\hline Pepper & 1.170 & 0.412 & 0.034 & 0.031 & 1.647 & 0.068 & 6 \\
\hline Coconut & 0.425 & 0.171 & 0.129 & 0.114 & 0.839 & 0.034 & 8 \\
\hline Beef cattle & 0.192 & 0.525 & 0.082 & 0.074 & 0.873 & 0.036 & 7 \\
\hline Sea weed & 0.088 & 0.033 & 0.912 & 0.936 & 1.969 & 0.081 & 3 \\
\hline Skipjack tuna & 0.031 & 0.086 & 1.337 & 0.470 & 1.924 & 0.079 & 4 \\
\hline Influence Index & 6.008 & 6.046 & 6.125 & 6.214 & & & \\
\hline
\end{tabular}




\subsubsection{South Konawe District}

Priority commodities identified in Konawe Selatan District included rice, soybean, cocoa, citrus, beef cattle, sea weed, milkfish, and nile tilapia. As shown in Table 5, three DMs put rice in the first priority, one DM selected cocoa, and another DM chose sea weed. Overall, rice obtained the highest weight, meaning that rice is the top-ranked commodity in South Konawe district. Cocoa was in the second position, followed by sea weed, beef cattle, citrus, soybean, milkfish, and nile tilapia.

Table 5. AHP based Borda results for ranking of commodities in South Konawe District

\begin{tabular}{ccccccccc}
\hline \multirow{2}{*}{ Alternatives } & \multicolumn{9}{c}{ Score (AHP*BC) } & \multirow{2}{*}{ Total score } & \multirow{2}{*}{ Weight } & \multirow{2}{*}{ Ranking } \\
\cline { 2 - 6 } & DM 1 & DM 2 & DM 3 & DM 4 & DM 5 & & \\
Rice & 0.966 & 2.576 & 1.267 & 2.096 & 2.504 & 9.409 & 0.320 & 1 \\
Soybean & 0.165 & 0.117 & 0.058 & 0.412 & 0.654 & 1.406 & 0.048 & 6 \\
Cocoa & 2.656 & 0.435 & 0.705 & 0.858 & 1.449 & 6.103 & 0.208 & 2 \\
Citrus & 1.428 & 0.021 & 0.140 & 0.69 & 0.255 & 2.534 & 0.086 & 5 \\
Beef cattle & 0.096 & 0.984 & 1.080 & 1.05 & 0.520 & 3.730 & 0.127 & 4 \\
Sea weed & 0.420 & 1.813 & 1.800 & 0.063 & 0.356 & 4.452 & 0.152 & 3 \\
Milkfish & 0.320 & 0.320 & 0.216 & 0.219 & 0.100 & 1.175 & 0.040 & 7 \\
Nile tilapia & 0.037 & 0.056 & 0.292 & 0.134 & 0.043 & 0.562 & 0.019 & 8 \\
Influence Index & 6.088 & 6.322 & 5.558 & 5.522 & 5.881 & & & \\
\hline
\end{tabular}

\subsubsection{Muna District}

Table 6 presents ranking of priority commodities in Muna district. Four of five DMs placed sea weed at the first choice, so that its total score was the highest among all alternatives. Based on the total score and weight, the first priority was given to sea weed. The second and subsequent priorities were beef cattle, maize, cashew nut, cocoa, shrimp, rice and cassava.

Table 6. AHP based Borda results for ranking of commodities in Muna District

\begin{tabular}{|c|c|c|c|c|c|c|c|c|}
\hline \multirow{2}{*}{ Alternatives } & \multicolumn{5}{|c|}{ Score $(\mathrm{AHP} * \mathrm{BC})$} & \multirow{2}{*}{ Total score } & \multirow{2}{*}{ Weight } & \multirow{2}{*}{ Ranking } \\
\hline & DM 1 & DM 2 & DM 3 & DM 4 & DM 5 & & & \\
\hline Rice & 0.210 & 0.138 & 0.036 & 0.034 & 1.414 & 1.832 & 0.062 & 7 \\
\hline Maize & 0.108 & 0.324 & 0.954 & 0.675 & 1.680 & 3.741 & 0.126 & 3 \\
\hline Cassava & 0.029 & 0.019 & 0.189 & 0.180 & 0.710 & 1.127 & 0.038 & 8 \\
\hline Beef cattle & 0.708 & 1.477 & 1.638 & 1.498 & 0.264 & 5.585 & 0.188 & 2 \\
\hline Cocoa & 0.445 & 0.942 & 0.630 & 0.384 & 0.488 & 2.889 & 0.097 & 5 \\
\hline Cashew nut & 0.316 & 0.540 & 0.292 & 1.008 & 0.876 & 3.032 & 0.102 & 4 \\
\hline Sea weed & 2.504 & 2.768 & 2.072 & 1.968 & 0.044 & 9.356 & 0.316 & 1 \\
\hline Shrimp & 1.743 & 0.066 & 0.098 & 0.092 & 0.090 & 2.089 & 0.070 & 6 \\
\hline Influence Index & 6.063 & 6.274 & 5.909 & 5.839 & 5.566 & & & \\
\hline
\end{tabular}

\subsubsection{Buton District}

Ranking of priority commodities in Buton District is summarized in Table 7. For the first priority commodity, two DMs wanted cashew nut, two DMs wanted rice, and another one chose maize. However, cashew nut got the highest weight, making it the top-ranked commodity in the district. Maize was on the second rank, followed by rice, coconut, sea weed, beef cattle, skipjack tune, and citrus.

Table 7. AHP based Borda results for ranking of commodities in Buton District

\begin{tabular}{|c|c|c|c|c|c|c|c|c|}
\hline \multirow{2}{*}{ Alternatives } & \multicolumn{5}{|c|}{ Score $(\mathrm{AHP} * \mathrm{BC})$} & \multirow[b]{2}{*}{ Total score } & \multirow[b]{2}{*}{ Weight } & \multirow[b]{2}{*}{ Ranking } \\
\hline & DM 1 & DM 2 & DM 3 & DM 4 & DM 5 & & & \\
\hline Maize & 1.106 & 2.352 & 0.456 & 1.344 & 0.114 & 5.372 & 0.195 & 2 \\
\hline Rice & 1.360 & 0.297 & 1.020 & 1.728 & 0.050 & 4.455 & 0.161 & 3 \\
\hline Beef cattle & 0.918 & 0.188 & 0.725 & 0.084 & 0.240 & 2.155 & 0.078 & 6 \\
\hline Cashew nut & 0.484 & 0.666 & 1.800 & 1.044 & 2.528 & 6.522 & 0.236 & 1 \\
\hline Coconut & 0.078 & 0.060 & 1.400 & 0.695 & 0.404 & 2.637 & 0.096 & 4 \\
\hline Citrus & 0.291 & 0.854 & 0.186 & 0.029 & 0.560 & 1.920 & 0.070 & 8 \\
\hline Sea weed & 0.625 & 0.432 & 0.041 & 0.303 & 1.162 & 2.563 & 0.093 & 5 \\
\hline Skipjack tuna & 0.194 & 0.555 & 0.086 & 0.428 & 0.708 & 1.971 & 0.071 & 7 \\
\hline Influence Index & 5.056 & 5.404 & 5.714 & 5.655 & 5.766 & & & \\
\hline
\end{tabular}




\subsubsection{Wakatobi District}

Seven priority commodities in Wakatobi district are sea weed, skipjack tuna, grouper, Indian scad, coconut, cassava and goat. The assessment results of five decision makers presented in Table 8 show that sea weed got the highest weight. Therefore, the first priority commodity in the district is sea weed. In the second and subsequent positions were cassava, grouper, goat, Indian scad, coconut, and skipjack tuna.

Table 8. AHP based Borda results for ranking of commodities in Wakatobi District

\begin{tabular}{|c|c|c|c|c|c|c|c|c|}
\hline \multirow{2}{*}{ Alternatives } & \multicolumn{5}{|c|}{ Score (AHP*BC) } & \multirow{2}{*}{ Total score } & \multirow{2}{*}{ Weight } & \multirow{2}{*}{ Ranking } \\
\hline & DM 1 & DM 2 & DM 3 & DM 4 & DM 5 & & & \\
\hline Sea weed & 1.098 & 1.110 & 1.799 & 1.337 & 1.463 & 6.807 & 0.283 & 1 \\
\hline Skipjack tuna & 0.186 & 0.279 & 0.704 & 0.069 & 0.448 & 1.686 & 0.070 & 7 \\
\hline Grouper & 0.324 & 0.186 & 1.025 & 0.855 & 0.192 & 2.582 & 0.107 & 3 \\
\hline Indian scad & 0.085 & 0.068 & 1.326 & 0.672 & 0.093 & 2.244 & 0.093 & 5 \\
\hline Coconut & 0.580 & 0.520 & 0.153 & 0.339 & 0.303 & 1.895 & 0.079 & 6 \\
\hline Cassava & 2.121 & 1.925 & 0.098 & 1.116 & 1.170 & 6.430 & 0.267 & 2 \\
\hline Goat & 0.448 & 0.775 & 0.041 & 0.204 & 0.970 & 2.438 & 0.101 & 4 \\
\hline Influence Index & 4.842 & 4.863 & 5.146 & 4.592 & 4.639 & & & \\
\hline
\end{tabular}

\subsection{Ranking Commodities at the Province Level}

To determine the rank of priority commodities at the province level, all alternative commodities at the district level were listed and given points based on their rank. The further analysis used Borda count method to get the final rank of each commodity. In this regard, if there are two or more commodities have the same score, their rank will be determined first by the frequency of their appearance in the list of alternative commodities at the district and then by their weight. Sea weed had the highest point, followed by rice and cocoa. This meant that sea weed was the first priority commodity in the province, whereas rice and cocoa were in the second and third position. Subsequent commodities in order of their ranking were beef cattle, maize, skipjack tuna, cashew nut, coconut, cassava, citrus, clove, grouper, goat, shrimp, soybean, milkfish, Indian scad, pepper, and nile tilapia.

Table 9. Point of priority commodities in Southeast Sulawesi province

\begin{tabular}{|c|c|c|c|c|c|c|c|c|}
\hline \multirow{2}{*}{ Commodity } & \multicolumn{6}{|c|}{ Borda Count } & \multirow{2}{*}{ Total Points } & \multirow{2}{*}{ Ranking } \\
\hline & Kolaka & Konawe & South Konawe & Buton & Muna & Wakatobi & & \\
\hline Beef cattle & 1 & 2 & 5 & 3 & 7 & - & 18 & 4 \\
\hline Cashew nut & - & - & - & 8 & 5 & - & 13 & 6 \\
\hline Cassava & - & - & - & - & 1 & 6 & 7 & 9 \\
\hline Citrus & - & - & 4 & 1 & - & - & 5 & 10 \\
\hline Clove & 5 & - & - & - & - & - & 5 & 11 \\
\hline Cocoa & 6 & 7 & 7 & - & 4 & - & 24 & 3 \\
\hline Coconut & - & 1 & - & 5 & - & 2 & 8 & 8 \\
\hline Goat & - & - & - & - & - & 4 & 4 & 13 \\
\hline Grouper & - & - & - & - & - & 5 & 5 & 12 \\
\hline Indian scad & - & - & - & - & - & 3 & 3 & 17 \\
\hline Maize & - & 4 & - & 7 & 6 & - & 17 & 5 \\
\hline Milkfish & - & - & 2 & - & - & - & 2 & 18 \\
\hline Nile tilapia & - & - & 1 & - & - & - & 1 & 19 \\
\hline Pepper & - & 3 & - & - & - & - & 3 & 18 \\
\hline Rice & 4 & 8 & 8 & 6 & 2 & - & 28 & 2 \\
\hline Sea weed & 3 & 6 & 6 & 4 & 8 & 7 & 34 & 1 \\
\hline Shrimp & - & - & - & - & 3 & - & 3 & 14 \\
\hline Skipjack tuna & 2 & 5 & - & 2 & - & 1 & 10 & 7 \\
\hline Soybean & - & - & 3 & - & - & - & 3 & 15 \\
\hline
\end{tabular}

\section{Discussions}

AHP based Borda results presented in Tables 2-7 show that each district has its own priority commodities depending on its agroecological and socio-economic conditions. For example, cocoa obtained the highest weight in Kolaka district, which is well known in Indonesia as the production center of cocoa (Akiyama \& Nishio, 1997). The first ranked commodity in Buton district is cashew nut, which grows well and has long been produced in the district (Zani, 2012). With respect to rice which obtained the highest weight in Konawe and 
South Konawe districts, the two districts are known as rice production centers in the province. Sea weed is a newly emerging potential commodity in Wakatobi and Muna districts as they have longer coastal line compared to other districts. Alternative commodities in Wakatobi district are dominated by those from fisheries subsector, reflecting the fact that the district is made up of four small islands, and $97 \%$ of its total area consists of sea water.

Tables 2-7 also show the variation in the ranking of commodities within a district according to decision makers. These differences may represent DMs' attitude toward the six criteria of priority commodities and, to a lesser extent, their tendency to put more weights to the commodity from their own office's jurisdiction (food crop, estate crops, fisheries, and livestock). In view of the diversity of decision makers' opinions and the two-stage process of selection (at district and provincial level), the combined use of AHP and BC is deemed suitable to achieve the objective of this study. In this way, specifically at the district level, the strength of the preferences and the consistency with each decision can be revealed through AHP, and how each decision maker influences the overall outcome can be known through influence index of BC (Claudio et al., 2008). Interestingly, the four top priority commodities in the province, namely sea weed, rice, cocoa, and beef cattle, represent the four subsectors (fisheries, food crops, estate crops, and livestock) in agriculture. Indeed, the final rank of priority commodities at the province level has reflected well the real condition of the province, consisting of districts with varying agroecological and socio-economic conditions.

With the use of Borda method, the final rank was determined in part by the frequency of a commodity being included in the list of alternative commodities at the district level. In other word, the more often a commodity is included in the districts' list of commodities, the higher chance its final ranking will be high. For example, sea weed was put as alternative commodity in every district, rice in five districts, and cocoa in four districts, making their total points being higher than others. Other commodities such clove, pepper, cassava, soybean, goat, nile tilapia, milkfish, shrimp, grouper and Indian scad became alternative commodities in only one or two districts, so their total points was also low. On one side, this is natural as each district has different priority commodities depending on its own unique conditions. One the other side, given the effect of such inclusion, it would be ideal if all districts could be selected as survey location to reinforce the conclusions from this study. However, although only half of the districts in the province were selected, the methodological procedures followed in the selection of districts render the results of this study meaningful, useful, and representative.

\section{Conclusions and Recommendations}

This paper proposed the combined use of AHP and BC to select priority commodities at the province level in Indonesia. In this method, the pairwise comparison among alternative commodities was done using AHP, followed by the use of BC to the AHP ranking. In this way, the use of AHP enables the decision maker to assign the magnitude of the preferences, measure their consistency, and see how each DM influences the overall outcome. The method is robust, simple, and flexible. The method could be applied as a reliable support tool in the real situations, characterized by diversity of problems and opinions, and imprecision of the decision maker's expertise and cognitive abilities. Given the busy schedule of decision makers, the method is practical as there is no need to gather them to have a meeting.

The results show that the first top priority commodity in the province is sea weed and the other nine top priority commodities in order of ranking are rice, cocoa, beef cattle, maize, cashew nut, skipjack tuna, coconut, cassava, and citrus. The provincial and district governments may use this information to renew its focus and commitment in terms of investment and policy interventions to develop agriculture sector. With the use of agribusiness approach that would develop a particular commodity in integrated and comprehensive ways, it is expected that agriculture sector can fulfil its development objectives, namely to increase the rate of food self-sufficiency, support food diversification, raise the competitiveness of agricultural production and value-added processing, and increase income of farmers.

\section{Acknowledgments}

Financial support provided by the Bank of Indonesia in Kendari is gratefully acknowledged. The author is grateful to Mr A. M. Yusuf for valuable administrative and technical assistance during the research work.

\section{References}

Akiyama, T., \& Nishio, A. (1997). Sulawesi's cocoa boom: Lessons of smallholder dynamism and a hands-off policy. Bulletin of Indonesian Economic Studies, 33(2). http://dx.doi.org/10.1080/00074919712331337145

BPS Sultra. (2013). Sulawesi Tenggara dalam angka. Kendari: BPS Sultra.

Claudio, D., Chen, J., \& Okudan, G. E. (2008). AHP based Borda Count: A hybrid multi-person decision making method for design concept selection. Proceedings of the 2008 Industrial Engineering Research Conference. 
Darji, V. P., \& Rao, R. V. (2013). Application of AHP/EVAMIX method for decision making in the industrial environment. American J. of Operations Research, (3), 542-569. http://dx.doi.org/10.4236/ajor.2013.36053

Dyer, R. F., \& Forman, E. H. (1992). Group decision support with the analytic hierarchy process. Decision Support Systems, 8(2), 99-124. http://dx.doi.org/10.1016/0167-9236(92)90003-8

FAO. (2001). The role of agriculture in the development of LDCs and their integration in the world economy. Paper prepared for the Third United Nations Conference on the Least Developed Countries, Brussels, 14-20 May. Retrieved from http://www.fao.org/docrep/003/y0491e/y0491e00.htm\#TopOfPage

Ichihara, G., \& Uchida, T. (2014). Prioritizing barriers to implementing more CDM projects in Indonesia: An application of AHP. Asian Social Science, 10(18), 191-201. http://dx.doi.org/10.5539/ass.v10n18p191

Junior, A. G. S., Perez, R., \& Boratto, M. (2010). Investment decision in vegetable oil extraction plants in north of Minas Gerais - Brazil: An application of the analytic hierarchy process in a biodiesel production chain. Proceedings of the $4^{\text {th }}$ International European Forum on System Dynamics and Innovation in Food Networks (pp. 391-399). University of Bonn/ILB Press.

Motik, D., Šegotić, K., \& Jazbec, A. (2010). Application of AHP model and survey results in deciding on a product line in furniture industry. Drvna Industrija, 61(2), 83-87.

Nainggolan, H. L. (2011). Peranan analisis komoditi unggulan bagi pengembangan tanaman pangan dalam rangka menciptakan kemandirian pangan di Kabupaten Toba Samosir. Buletin Ketahanan Pangan, 4(1), 26.

Nurmi, H. (2004). A comparison of some distance based choice rules in ranking environments. Theory and Decisions, 57(1), 5-24. http://dx.doi.org/ 10.1007/s11238-004-3671-9

OECD. (2012). OECD Review of Agricultural Policies: Indonesia 2012. OECD Publishing. http://dx.doi.org/10.1787/9789264179011-en

Otsuka, K. (2012). Economic transformation of agriculture in Asia: Past performance and future prospects. Asian Journal of Agriculture and Development, 9(1), 1-19.

Rao, R. V. (2013). Decision making in manufacturing environment using graph theory and fuzzy multiple attribute decision making methods. Springer Series in Advanced Manufacturing. London: Springer. http://dx.doi.org/10.1007/978-1-4471-4375-8

Saaty, T. L. (1980). The analytic hierarchy process: planning, priority setting, resource allocation. New York. NY: McGraw-Hill International Book Company.

Shapira, A., Shoshany, M., \& Nir-Goldenberg, S. (2013). Combining analytical hierarchy process and agglomerative hierarchical clustering in search of expert consensus in green corridors development management. Environmental Management, 52, 123-135. http://dx.doi.org/10.1007/s00267-013-0064-2

Srdjevic, Z., Lakicevic, M., \& Srdjevic, B. (2013). Approach of decision making based on the analytic hierarchy process for urban landscape management. Environmental Management, 51, 777-785. http://dx.doi.org/10. 1007/s00267-012-9990-7

Timmer, P. (2012). Structural transformation, the changing role of rice, and food security in Asia: Small farmers and modern supply chains. Asian Journal of Agriculture and Development, 9(1), 21-35.

Vaidya, O. S., \& Kumar, S. (2006). Analytic hierarchy process: An overview of applications. European Journal of Operational Research, 169(1), 1-29. http://dx.doi.org/10.1016/j.ejor.2004.04.028

Vizzari, M., \& Modica, G. (2013). Environmental effectiveness of swine sewage management: A multicriteria AHP-based model for a reliable quick assessment. Environmental Management, 52, 1023-1039. http://dx.doi.org/10.1007/s00267-013-0149-y

Widayanto, B. (2000). Kajian sektor unggulan dan transformasi struktur perekonomian di Kabupaten Sleman. DIY. Jurnal Dinamika Sosial Ekonomi Pertanian, 1(1), 51-70.

Zani, M. (2012). Analisis keuntungan dan efisiensi pemasaran kacang mete di Provinsi Sulawesi Tenggara (Unpublished Master Thesis). Halu Oleo University, Kendari, Indonesia.

\section{Copyrights}

Copyright for this article is retained by the author(s), with first publication rights granted to the journal.

This is an open-access article distributed under the terms and conditions of the Creative Commons Attribution license (http://creativecommons.org/licenses/by/3.0/). 